\title{
Passwords
}

Volume 12 | Issue 2

Article 16

6-4-2012

\section{Catgirl and Other Details (1996/7, Season Unknown)}

Olivia Weissbaum

ogw02010@mymail.pomona.edu

Follow this and additional works at: http://scholarship.claremont.edu/passwords

Part of the Creative Writing Commons

\section{Recommended Citation}

Weissbaum, Olivia (2012) "Catgirl and Other Details (1996/7, Season Unknown)," Passwords: Vol. 12: Iss. 2, Article 16. DOI: 10.5642/passwrd.20121202.16

Available at: http://scholarship.claremont.edu/passwords/vol12/iss2/16

This Story is brought to you for free and open access by the Journals at Claremont at Scholarship @ Claremont. It has been accepted for inclusion in

Passwords by an authorized administrator of Scholarship @ Claremont. For more information, please contact scholarship@cuc.claremont.edu. 


\section{Catgirl and Other Details (1996/7, Season Unknown) \\ Olivia Weissblum}

At four years old, I am a cat. I wear my ears day and night. They are perky and cardboard. Sometimes I also wear a tail and whiskers. I meow and walk on my knees. I don't understand purring yet.

The teacher is an older, stout, frowny woman with cropped gray hair and lines around her mouth. She says garbazh because it makes her sound French (or so she jokes, perhaps, I cannot tell at this time) and once advised us to hold our scissors inward when we run with them, so as to stab ourselves instead of others in the event of a collision. She runs snack-time on a strict capitalist basis - the big kids always get there first, but You Get What You Get. It's her cross-armed singsong chant. Orange slices, hot dogs, dirt in a cup, nothing. You Get What You Get.

I'm not a cat anymore today. The teacher told me that I have to be myself, and I'm not sure what that is, but I guess it's not a cat. 